\title{
Contribution of Women in Influencing Legislation and Policy Formulation and Implementation in Uganda (1995-2005)
}

\author{
Elijah Dickens Mushemeza*
}

\begin{abstract}
$^{1}$
This paper on impact assessment of the contribution of women in influencing legislation and policy formulation and implementation in Uganda 1995-2005 is premised on the assumption that there is still much more to be done, though women have made some contributions towards the advancement of gender equality and empowerment. This is because the institution of patriarchy is still strong, and sufficient gender mainstreaming in the determination of policy choices and legislations and how these affect the quality of life for both women and men, particularly in the areas of family, health and education, is still lacking. The paper argues that although the government has been implementing a gender sensitive and responsive constitution, and despite the fact that the number of women participating in politics and governance has been steadily increasing, their participation has not had the desired impact on legislations and policies to make them gender sensitive and responsive to women's rights, interests and needs. The sectors of health, education and family are selected for the analysis because these are where women are affected most. It is presumed that having gender sensitive, responsive and implemented policies, and non-discriminatory laws, in these sectors would go a long way in neutralising patriarchy and promoting gender equality and women's empowerment.

The paper proposes policy recommendations on how to scale up women's participation, contribution and impact on policies and legislations to the advancement of gender equality and empowerment of women in the entire society.
\end{abstract}

* Faculty of Business and Development Studies, Bishop Stuart University, Mbarara, Uganda. Email: emushemeza@yahoo.com or mushemeza@ss.mak.ac.ug. 


\begin{abstract}
Résumé
Cette étude sur l'évaluation de l'impact de l'influence des femmes dans l'élaboration et la mise en œuvre des lois et politiques en Ouganda entre 1995 et 2005 se fonde sur l'hypothèse selon laquelle il reste encore beaucoup à faire, même si les femmes ont fait progresser la lutte pour l'égalité des sexes et l'appropriation des sphères économiques, sociales et politiques par les femmes,. Cette situation s'explique par le fait que le patriarcat reste encore une institution forte, et que l'intégration du genre dans la détermination des choix politiques et des lois, et la manière dont ces derniers influencent la qualité de vie des femmes et des hommes est encore loin d'être satisfaisante.

Certes, le gouvernement applique une constitution sensible et réactive aux questions liées au genre et le nombre des femmes participant au jeu politique et à la gouvernance s'est régulièrement accru. Cependant, cette étude estime que leur participation n'a pas provoqué l'effet escompté sur les lois et les politiques au point de les rendre sensibles aux questions liées au genre et réactives aux droits, aux intérêts et aux besoins des femmes. L'étude recommande donc des politiques permettant le renforcement de la participation et de la contribution des femmes ainsi que de leur l'influence sur les politiques et les lois œuvrant à l'égalité des sexes et à l'autonomisation des femmes dans l'ensemble de la société.
\end{abstract}

\title{
Introduction: Women in Governance in Historical Perspective
}

The struggle for women's emancipation in Uganda has a long history. The women's movement in Uganda is one of the strongest mobilised societal forces. Its history can be traced during the colonial period and in the activities after independence under the first Milton Obote regime (1962-1971). Unfortunately, Idi Amin suppressed the women's organisations, until they re-emerged under Obote's second regime (1980-1985). The National Council of Women (NCW), which was established by a decree and placed under the Ministry of Community Development, was a response to a United Nations Resolution, an initiative of the UN decade for women. However, the NCW lacked independence and the decree which established it was used by the government to limit the formation and registration of progressive women's NGOs. Even then the struggle for emancipation lacked the revolutionary zeal and focus as Matembe (2002:65) recounts.

Until the changing times of the mid-1980s, the general view of women in Uganda was very traditional and limiting. Women were thought to be first and foremost wives and mothers. Domestic space was women's domain and their main responsibilities were family related. Generally, women were not perceived to be public actors or public decision makers. 
Subsequently, when the National Resistance Movement took over power in 1986, the women's movement gained much more support because the political leaders were ready to listen to concerns relating to oppression of and discrimination against women. During the constitution drafting process (1988-1995), the major concern on women was the long history of their systematic oppression and discrimination throughout the pre-colonial, colonial and post-independence eras. Concerns were also articulated in the sectors of education, family and health.

In the education sector, it was also observed at the time that girls were discriminated against. Boys' education was always preferred. Whenever parents failed to raise sufficient funds, girls were the first to be recalled from schools. Girls who became pregnant were denied a chance to continue their education while the boys responsible got off the blame and continued to study.

In the family sector, concerns were raised about laws which discriminate against them in several aspects: property ownership, marriage, separation, divorce, custody of children and inheritance. It was noted that in our societies women were often denied the right to own property. Whatever a woman owned before marriage belonged to her family while after marriage every thing belonged to the husband and his relatives or clan. Daughters were excluded from becoming heirs to their fathers even where there was no son in the family.

In some communities, the widow was regarded as 'property' to be inherited as part of estate (The Report of the Uganda Constitutional Commission 1993). There were also cultural practices that were identified as inconsistent with modernity, health and development ideals. These included the practice of forcing young girls into marriage, the payment of bride-price, its commercialisation and the negative connotations it carries, the traditions of widow inheritance, female circumcision and prohibiting women and children from eating certain nutritious foods. All these became important issues for debate, scrutiny and attention.

The above concerns were made against a background of understanding that Uganda was already a signatory to various International legal instruments, including the Convention on the Elimination of all Forms of Discrimination against Women (1979). The challenge has been on how to translate the state's obligation towards international agreements it has ratified into effective legislation, policy and action.

Furthermore, Uganda's past three constitutions 1962, 1966 and 1967 all carried bills of human rights and fundamental freedoms. The bills focused on civil and political rights and fundamental freedoms like the right to life, 
personal liberty, individual property, etc. and fundamental freedoms like freedom of movement, expression, assembly and association. However, the bills of rights in those constitutions did not make provision for the enjoyment of economic, social and cultural rights like right to education, employment, social security, good health and adequate standard of living. The constitutions also do not capture the equality of gender in enjoying the civil, political, social, economic and cultural rights. The constitutions also did not mention gender equality in enjoying these rights and, apart from the courts of law, provided no other institutions for the enforcement of human rights observance, particularly on gender inequalities. Worse still, there were no policies to deal with awareness and service delivery on gender as a development concern among policy makers and implementors. Similarly, the family law, particularly the Marriage Act (1904), Divorce Act (1904), Succession Act (1906) were not amended after independence to be gender compliant.

\section{Situation Analysis}

Uganda over the last twenty years has made some achievements towards gender equality and empowerment of women. Indeed, as the Uganda Gender Policy (2007) points out, key positive milestones and gaps can be highlighted in the sectors of our interest (education, health, family) in this paper.

The Universal primary Education (UPE) has increased overall enrollment from 2.7 million in 1995 to 5.3 million in 1997 and to 7.3 million in 2002 with girls constituting 49 per cent (3.6 million); in 2005 it rose to 49.6 per cent (3.6 million) and increased to 50 per cent (3.65 million) in 2006. When affirmative action for females was introduced in public universities, it increased female enrollment from 23.9 per cent in the academic year 1989/90 to 29.2 per cent in 1990/91 and then to 49.5 per cent in 2003/04; and 45.2 per cent in 2005/ 2006. Literacy rates increased from 54 per cent in 1991 to 69.6 per cent in 2002. The imbalance emanates from varying levels of enrollment and attendance of education at all levels. Overall, 77 per cent of the males are literate compared to 62.4 per cent of the females (2002 Population and Housing Census).

In the health sector, there has been declining trend of HIV infection from a peak of 18 per cent in 1992 to 7 per cent in 2005. However, among 15-49 year olds, HIV/AIDS prevalence amongst women is at 7.8 per cent as compared to 6.4 per cent for men. Amongst urban females, it is at 12.8 per cent compared to 6.5 per cent for those in rural areas. By the age of 15 years, 16 per cent of women are married while 53 per cent are by the age of 18 (UDHS 2006). Rural water coverage increased from 54.9 per cent in 2002 to 61 per cent in 2006. On health rights, high mortality and mobility rates remain a challenge. The Uganda Demographic and Health Survey (2006) revealed an infant mortality rate of 76 deaths per 1,000 live births and under 
five mortality rate of 137 per 1,000 births. The UDHS 2000/1 put maternal mortality ratio at 505 per 100,000 live births. The high total fertility rate at 6.9 per cent has led to the rapidly increasing growth rates (3.3\%) per annum, which in turn has negative consequences on provision of health services for women and increases the dependence ratio. The high incidence of teenage pregnancies is associated with high risks to health and life of both mother and child (UGP 2007:9-10).

In the family sector, a number of gaps exist in terms of achieving equality and empowerment of women. A gender analysis of Uganda National Household Survey (UNHS 1992-2003) data indicates that around 20 per cent of Ugandan households are chronically poor and more than 10 per cent of the poorest households moved into poverty between 1992 and 1999. The Uganda Strategic Country Gender Assessment (World Bank 2005) revealed that women bear the brunt of domestic tasks, in addition to agricultural and other productive work.

In Uganda, there is evidence of critical gender related barriers to access to justice. These include substantive law issues relating to gender biased laws (particularly concerning divorce, adultery and defilement) and differences in burden of proof requirements, administration of law issues including physical access, training and orientation of staff and delays in the delivery of justice. There are significant gender inequalities with regard to the right to property. Land is a critical resource for over 90 per cent of households in Uganda, and women own only 16 per cent of the registered land (Gender Baseline Study: Land Sector, 2004). Apart from a few, economically advantaged women, the majority have only user rights determined by the nature of the relationship they have with a male land owner-father, husband or brother (UGP 2007:9).

Furthermore, gender based violence in its various forms (domestic violence, sexual harassment, trafficking, rape and defilement) is still a critical concern to the Ugandan society. The UDHS (2006) indicates that 60 per cent of the women and 53 per cent of the women aged 15-49 years experience physical violence, 39 per cent of the women experience sexual violence while 16 per cent experience violence during pregnancy. Similarly, it was reported that 48 per cent of ever married women reported physical violence by their husband or former husband (UGP 2007:10). Furthermore, in the family sector, laws on domestic relations, inheritance, domestic violence, sexual offences and on land and property remain negative and oppressive to the advancement of gender equality and women's empowerment.

In the light of the above observations, our concern in this paper is to interrogate the contribution of women in policy and legislation formulation and implementation to address the concerns that were identified during the 
constitution drafting process and the current remaining policy and legislation gaps particularly in the family, health and educational sectors. Our main argument is that although women as individuals and groups and/or networks have made some contributions towards advancement of gender equality and empowerment of women in economic, social and political spheres, there is still much more to be done. This is because the institution of patriarchy is still strong and sufficient gender mainstreaming in the determination of policy choices and legislations and how these affect the quality of life for both women and men particularly in the areas of family, health and education is still lacking in Uganda.

In analysing the above research issue, the concept contribution was found to be problematic. Policy and legislation formulation and implementation is done by various actors in society, including both men and women. Successes and failures cannot be attributed to one gender. Therefore, singling out the contribution of women alone poses conceptual dilemmas. Nevertheless, we have devised a conceptual framework that dissects the concept contribution and how it can be measured qualitatively and which also presents benchmarks that will help to carry out an impact assessment of the women's contribution over the years.

\section{Conceptual Framework}

To assess the impact of the contribution of women in formulation and implementation of legislations and policies in the health, education and family sectors, it is important to identify the relevant legislations and policies in those sectors. It is also vital to analyse the extent to which women as individuals and groups or networks have influenced the legislations and policies in terms of gender mainstreaming, participation, recognition of women's role in the provision and use of resources, integrated planning, financial framework and advocacy. But what do these benchmarks really mean?

Gender mainstreaming, the first benchmark, is a process to ensure that the concerns and needs of both women and men are considered in all planning and policy-making and that all policy-makers are aware of the needs of women and men and their roles and responsibilities. It is a conscious approach of an organisation to take into account gender equality concerns in all policy, programme, administrative and financial activities as well as organisational structures and procedures. In order to realise gender mainstreaming, it is important to modify the legal framework. Is the legal treatment of men and women equal? Are men and women equal under and before the law? Are gender-issues integrated into the constitution?

Similarly, the establishment of a political framework for using targeting measures to narrow the gender gap is crucial for gender mainstreaming. To have a viable political framework and to monitor the legal framework, an 
institutional framework for gender issues must be established and functional. To what extent have the women pushed and realised a political, legal and an institutional framework which facilitate gender equality and women's empowerment? Has the institutional framework enabled women to fully realise the desired affirmative action?

Furthermore, a financial framework is crucial for realising gender-aware policies and to demonstrate political commitment to gender mainstreaming by allocating sufficient resources to gender integrated policies. How have women worked towards achieving such a framework?

The second benchmark is participation. With some exceptions, women are generally under-represented at the decision-making level in the most critical sectors and are rarely consulted regarding public projects. Sometimes, women are placed below men as Vice-chairpersons when clearly the women are better qualified and more capable. It is important for every progressive government to always consult women leaders at various levels and ensure their participation in order to formulate legislations and policies that reflect their needs and demands. Consultations are also necessary when appointments are being considered, so that capable women are selected.

If this is not done, the tendency to blame all women when one woman disappoints the society will persist. A participatory framework is therefore crucial for involving beneficiaries in public policy through stakeholdersparticipation by working in collaboration with government, development organisations, and civil society organisations. Ultimately, women's equal participation, their perspectives, knowledge, and experiences are all crucial to the creation of a more just, prosperous, and peaceful nation. Participation therefore implies contributing and taking part in the implementation of, and benefiting from development interventions, including resource allocation and utilisation, as well as decision making, planning, and administration. The question for us is: 'to what extent have women been consulted and involved in the formulation and implementation of the existing policies and legislations in the health, education and family sectors?'

The third benchmark is the recognition of women's role in the provision and use of resources. A progressive policy and legislation in which women's contribution is reflected should recognise women's role in the provision and use of resources in relation to their needs. To what extent have women promoted gender and equity budgeting? Gender and equity budgeting does not produce a separate budget but is an analytical tool applied to mainstream budgetary processes.

The fourth benchmark is integrated planning. The contribution of women should shape policies to have an integrated planning (IP) approach, which recognises that gender issues have multi-disciplinary (political, social, 
economic and environmental) aspects. Gender mainstreamed policies should promote a demand-driven approach towards planning. Policies that have gender awareness should promote the production of gender-disaggregated data on males and females. This can be used as a tool to enlarge the knowledge of women on the use of resource and how to articulate their demands.

This conceptual framework should help us to make an impact assessment and analyse how women's groups/networks, and even women in government departments, have influenced policy and legislation making and implementation to the advancement of gender equality and women's empowerment.

\section{International and Constitutional Provisions that Create Political Space for Women}

\section{The Existing Legal Framework}

Prior to the 1995 Constitution, there were hardly any policies that focused on the advancement of gender equality and empowerment of women in health, education and family. Although there were legislations in education (Education Act 1970) and in the family sector - the Marriage Act (1904), Divorce Act (1904), Succession Act (1906) existed. However, none of these laws were gender compliant and yet no government at the time made attempts to amend them.

Women in Uganda constitute the largest single social group, comprising 51 per cent of its population according to the 2002 Census. Uganda recognises the importance of protecting women's rights because of their vulnerability. Indeed, women's vulnerability arises from their unequal social status and from the unequal power relations they have with men. Women's responsibilities in care giving, economic production and community activities give them a heavy work burden. This makes women generally poorer than men.

To promote and protect the rights of women, Uganda is a signatory to the Convention on the Elimination of All Forms of Discrimination against Women (CEDAW) 1995 but is yet to sign its optional protocol. Furthermore, CEDAW states that... 'the full and complete development of the country, the welfare of the world and the cause of peace require the maximum participation of women on equal terms with men in all fields'.

The convention provides the basis for realising equality between women and men through ensuring women's equal access to and equal opportunities in political and public life as well as education, health and employment. It affirms the reproductive rights of women, and targets culture and traditions as influential in shaping gender roles and family relations. Countries that have signed or ratified the convention are legally bound to put provisions into practice. It basically defines what constitutes discrimination against women and sets up an agenda for national action to end such discrimination. 
According to the convention, discrimination against women is defined as '... any distinction, exclusion or restriction made on the basis of sex which has the effect or purpose of impairing, nullifying the recognition, enjoyment or exercise by women, irrespective of their marital status, on a basis of equality of men and women of human rights and fundamental freedoms in the political, economic, social, cultural, civil or any other field'. States committed themselves to undertake a series of measures to end discrimination against women in all forms, including:

- To incorporate the principle of equality of men and women in their legal system, abolish all discriminatory laws and adopt appropriate ones prohibiting discrimination against women;

- To establish tribunals and other public institutions to ensure the effective protection of women against discrimination, and;

- To ensure elimination of all acts of discrimination against women by persons, organisations or enterprises.

In 1995, the fourth World Conference on women took place in Beijing and produced an outcome document popularly known as the Beijing Declaration and Platform for Action. It set out its goals as gender equality, development and peace and constituted an agenda for the empowerment of women. 'The objective of the Platform for Action is in full conformity with the purposes and principles of the charter of the United Nations and international law and that is the empowerment of women. The full realisation of all human rights and fundamental freedoms of all women is essential for the empowerment of women'. Uganda participated and supports the Beijing Document. The Beijing Platform for Action identified 12 critical priority areas to achieve the advancement and empowerment of women. Uganda also supports and is a signatory to the Common Wealth Plan of Action on Gender Development: Advancing the Common Wealth Agenda into the New Millennium (20052010), the International Conference on Population and Development (1994), and The Convention on the Rights of the Child (CRC 1990).

Together with 190 other governments, Uganda signed the United Nations Millennium Declaration (MDG) in 2000 and is working towards the achievement of eight measurable, time-bound Millennium Development Goals, centered on having poverty reduced by 2015. MDG 3 is aimed at promoting gender equality and women empowerment.

At the regional level, government of Uganda is signatory to the African Charter on Peoples and Human Rights; the East African Community (EAC) (2000); the Common Market for Eastern and Southern Africa (COMESA) Gender Policy (May 2002); the Protocol on the Rights of Women in Africa 
(July 2003); the Intergovernmental Authority on Development (IGAD), Gender Policy and Strategy (July 2004); the New Partnerships for African Development (NEPAD), Social Indicators Programme and the AU Heads of State Solemn Declaration on Gender Equality (July 2004).

At the national level, the Constitution of the Republic of Uganda makes a commitment to the promotion and protection of social justice and equality of all Ugandans. One of the national objectives is empowerment and encouragement of active participation of citizens, including women, in their governance at all levels. The Constitution further states that all Ugandans, including women, shall have access to leadership positions at all levels in Uganda. The Constitution under National Objectives and Principles of State Policy (VI) stresses that the State shall ensure gender balance and fair representation of marginalised groups on all constitutional and other bodies.

From a gender perspective, the Constitution of the Republic of Uganda is acclaimed as being one of the gender sensitive constitutions in Africa. This fact is testified to by a number of articles that include:

- Article 21 which provides for equal treatment in all spheres of life under the law, regardless of sex;

- Article 26(1) which protects all persons from deprivation of property;

- Articles 31(1) which entitles women and men to equal rights during and after marriage;

- Article 32(1) which mandates the State to take affirmative action in favour of groups marginalised on the basis of gender or any other reason created by history, tradition or custom;

- Article 33(4) which further asserts that the State shall provide facilities and opportunities necessary to enhance the welfare of women to enable them realise their full potential and advancement;

- Article 33(5) which accords affirmative action to women for purposes of redressing the imbalances created by history, tradition or custom. It should be noted here that the Uganda Parliament is composed of 32.2 per cent women and at local government level, women hold 30 per cent of the positions;

- Article 33(6) which prohibits 'laws, cultures and traditions, which are against the dignity, welfare or interest of women and undermine their status';

- The Constitution also mandates Parliament, among other things, to make laws for the establishing of an Equal Opportunities Commission (EOC) for the purpose of giving effect to constitutional mandates expressed therein. 
As noted above, Article 32 of the Constitution promotes affirmative action in favor of marginalised groups, including women. Apart from being eligible and able to compete equally with men to represent all the constituencies in Parliament, women have been reserved a special seat (Woman District Member of Parliament - MP) to represent each of the districts of Uganda. This affirmative action has increased the number of women in politics and in positions of decision making. By the end of 2007, there were 103 women Members of Parliament, 80 of them as a result of affirmative action representing districts while the rest represent interest groups (Youth, PWDs, Army, and Workers). This has enhanced acceptance of women as leaders and has increased their self confidence and leadership skills. In other words, the main achievement of affirmative action is the increased level of representation and participation of women in politics and decision making, both at the national and local levels. Increased number of women in politics and decision making has enhanced their visibility in public office, legitimised their presence in areas previously considered to be male domain, and de-mystified some of the public offices such as that of the Vice President. Women in politics and decision making at all levels have provided role models for other women, with the result that more women today are willing to stand for political positions than was the case earlier.

As will be discussed later, despite these achievements, the aspect of affirmative action related to representation in politics and decision making has tended to overshadow other aspects of the policy, and yet, affirmative action is a short-term measure aimed at redressing imbalances caused by history, tradition and custom which should not be limited to political representation.

\section{Actual Practices: Selected Policies and Legislations in Health, Education and the Family Sectors in which Women have Made a Contribution}

\section{Political and Institutional Framework}

As noted above, the legal framework for mainstreaming gender was embedded in the Constitution of 1995. Subsequently a political framework was established with the publication of the National Gender Policy in 1997. This was crucial for gender mainstreaming, and targeting measures to narrow the gender gap is crucial for gender mainstreaming. To implement the political framework and to monitor the legal framework, an institutional framework for gender issues was also established, which is now the Ministry of Gender, Labour and Social Development (MGLSD). Section 6.0 of the Uganda 
Gender Policy (2007) points out that the Ministry of Gender, Labour and Social Development, has the overall responsibility of spearheading and coordinating gender responsive development, and in particular ensuring the improvement in the status of women. The national machinery as part of the government provides policy guidelines on gender, gives technical support in gender mainstreaming to stakeholders and is involved in the development of gender policies in other sectors, acting both as a catalyst and a facilitator/ expert on gender issues. A major task of the Ministry is to organise seminars and workshops to sensitise different categories of policy makers and programme planners to gender issues. The target group is ministers, permanent secretaries, senior officials, members of district development planning committees; men and women a task which the Ministry has not been able to accompolish.

\section{Mechanisms for Gender Mainstreaming}

Technical, institutional and policy framework in gender mainstreaming are part of some of the efforts that have been undertaken by the government support legal reforms. Uganda, like many other African countries, has committed itself to implementing the international instruments and programmes of action. As noted earlier, in 1985, Uganda committed itself to the Convention on the Elimination of All Forms of Discrimination against Women (CEDAW) without any reservations. Uganda has been an active participant in the International Conferences on women. In addition to CEDAW, Uganda has committed itself to implement the Beijing Platform for Action. In 1988, The Ministry of Women in Development was started by Government to act as the lead agency in the task of improving the status of women. In 1991, it became the Ministry of Women, Youth and Culture. The change brought limited focus on gender due to the new functions of youth and culture that were added.

In 1994, the Ministry was restructured to include community development. It was renamed as the Ministry of Gender and Community Development. In 1999, it was again restructured to become the Ministry of Gender, Labour and Social Development.

The restructuring processes aimed at increasing efficiency and effectiveness of the civil service; reducing government expenditure and motivating workers. Retrenchment led to reduction of the Ministry staff to a skeletal level that could hardly cover the whole country, taking into account the policy and implementation of decentralisation. While planning took place at district level, there were no Gender Officers (technical staff). This undermined the initial efforts that had been undertaken to mainstream gender in the government 
planning processes (Keller 2002; Ssonko 2002) and also reduced the Ministry's visibility as the national machinery for bridging the gender gap.

The Ministry of Gender, Labour and Social Development has been one of the most under-funded ministries. Since its inception, it largely depended on funds from DANIDA that were terminated in 1998 because, according to DANIDA, the Government was not meeting its financial obligations as a 'counterpart to DANIDA funding' (Keller 2002). In spite of this, the Ministry, under the leadership of women, has made some improvements in providing and building the national machinery; for example, by initiating adult literacy programmes and teaming up with women networks to have the Equal Opportunities Commission (EOC) Act and Policy passed by Parliament.

With the backing of the Ministry of Gender, Women's Councils were established under the National Women's Council Act 1993. These are structures that are charged with the responsibility of fostering the social and economic development of women. However, as one respondent during the research that preceded this paper remarked, 'women councils have only been used for political purposes rather than fostering economic development. Women councils are used as mobilisation tools for political campaigns' They are composed of five women and start at Local Council levels one (village level and smallest government unit of administration) to local council five (district level). The chairpersons of the Women ouncils I and II become automatic members of Local Councils I and II respectively. However, when it comes to Local Council III upwards, the two structures are separated and there is no relationship between them. Indeed, the women council statute is not provided for in the Local Government Act and is hence not recognised as a structure by the Local Government. Therefore, women Councils do not receive funding or technical support from local governments. Under multi party system, there have been calls to remove the women councils.

National Gender Policy: In spite of the above institutional provisions, the Ministry has done some recognisable work on gender; for example, it prepared the National Gender Policy that was approved by the cabinet in 1997.The overall goal of the gender policy is to mainstream gender concerns in the national development process in order to improve social, legal/civic, political, economic and cultural conditions of people in Uganda particularly women. It recognises gender relations as a development concept in identifying and understanding the social roles and relations of women and men of all ages and how these impact on development.

The National Action Plan (1999/2000 - 2003/2004) identified four critical areas of concern for the government of Uganda. These were poverty, income generation and economic empowerment; reproductive health and rights; legal 
framework and decision making; and the girl child and education (Ministry of Gender 1998). The first disadvantage, however, was that the relationship between this plan and the other national development plans was not clear. Secondly, it was developed without any financial considerations or a monitoring and evaluation framework.

Nevertheless, under the leadership of able women, as Table 1 shows, and with support of women Civil Society Organisations, the Ministry undertook to appraise the effectiveness of the National Gender Policy. This was with the recognition that the national development process in Uganda has not been static. The adoption of major policy shifts like the Poverty Eradication Action Plan and Decentralisation Policy which were major policy shifts warranted the revision of the NGP. The revised version makes clear links to all major policy initiatives in Uganda (NGP 2007:v). 'We are yet to see how the revised National Gender Policy impacts on other policies in place or those that are yet to be formulated'.

Table 1: Gender Categorisation of Key Decision Makers in the MGLSD

\begin{tabular}{lcl}
\hline Position & Female & Male \\
\hline Minister & 1 & 2 \\
State Ministers & 1 & \\
Permanent Secretary & 1 & \\
Director Gender & 1 & 1 \\
Director Labour & & \\
Under Secretary & 1 & \\
Commissioners & 2 & 1 \\
Assistant Commissioners & 2 & \\
Principal Asst Sec & & \\
Principal Accountant & 1 & 4 \\
Principal personnel officer & 1 & \\
Total & 11 & \\
\hline
\end{tabular}

Source: Field Data, October 2007

\section{Health Sector}

\section{National Health Policy}

In 1993, the Ugandan government produced a Health Policy White Paper and a three-year Plan Frame 1993-1996 (extended to 1997/98). During this planning period, health policy focused on consolidating existing PHC services and addressing AIDS. From 1998 onwards, the eradication of poverty in the health sector became the priority. 
The development of a new national health policy for Uganda for the period 1999-2009 began in 1996; the policy was approved by the cabinet in 1999 . The New policy signifies a transition from emergency relief operations within the health sector to a social development perspective on health (Ministry of Health 1999a). Its overall policy goal for the current National Health Policy (1999-2009) is the attainment of good standard of health by all people in Uganda, in order to promote a healthy and productive life (NHP 1999).

Gender Mainstreaming: The National Health Policy is gender compliant. Its guiding principle (i) states that: a gender sensitive and responsive national health system shall be achieved through mainstreaming gender considerations in planning and implementation of all health programmes. Gender sensitivity will require that gender related barriers to health care be removed. Equal weight shall be given to knowledge, values and experience of women and men, and that they participate equally in research, policy and decision making. Sexuality and sexually related behavior and gender relations including child sexual abuse, violence against women, genital mutilation and other harmful practices shall be routinely taken into consideration and addressed in collaboration with the relevant stakeholders.

Under the Uganda National Minimum Health Care Package (UNMHCP) a mechanism that should allow cost-effective, integrated implementation of health problems, gender mainstreaming comes out prominently. The minimum health care package consists of the following: control of communicable disease (malaria, STI/HIV/AIDS, Tuberculosis); integrated management of childhood illnesses; sexual and reproductive health rights (sexual ante-natal and obstetric care, family planning, adolescent reproductive health, violence against women); and other public health interventions. Under Section 6 - Health Financing, government commits itself to focus the use of public resources (including official development assistance) on health services that are demonstrably cost-effective, have the greatest impact on reducing mortality and morbidity, and/or have a clear bias to protecting the poor and most vulnerable population as well as taking due consideration of the gender related health care needs and concerns.

Participation of Women in Formulating the Policy: Policy formulation involved a wide range of stakeholders. This is reflected in the concluding section of the NHP which provides that:

The consultative process that was applied in developing this policy document has generated wide consensus on the priority health development objectives and the strategies for achieving them. It is hoped that the same spirit of collaboration will prevail during period of implementation (NHP 1999). 
Participation in policy formulation through national workshops is however viewed by some women as inadequate. During the research that generated the data for this paper (interviews), views of such nature came up from well known academic intellectuals. For example, one observed that:

The process of policy making is more internal and many women are not involved. Some of us are brought in at the last minute to make comments or critique what is presented during workshops (interview with Grace Bantebya).

Similarly, implementation of policy is not gender compliant as one of the respondents recollects:

In the Ministry of Health, we can say ideally women participate but at lower levels of carrying out their work. But if we talk of decision making, there is no participation because there are few women in positions that matter to take decisions. For example, $\mathrm{MoH}$ has only one woman placed in the decision making bracket as a Permanent Secretary who has been in that decision for less than one year. Perhaps, the other woman I can point out is the head of nurses. So we cannot expect women to take decisions or influence policy when they are not at the top decision making level (interview with Christine Mubiru).

The above observation is supported by the findings as Table 2 summarises the gender representation in the Ministry of Health $(\mathrm{MoH})$ at the top management level.

Table 2: Gender Categorisation of Key Decision Makers in the Ministry of Health

\begin{tabular}{lcc}
\hline Position & Female & Male \\
\hline Minister & 2 & 1 \\
State Ministers & 1 & \\
Permanent Secretary & & 2 \\
Directors & 1 & \\
Director General & & 1 \\
Under Secretary & 1 & 7 \\
Commissioners/Heads of Departments & & 2 \\
Assistant Commissioners & 2 & 16 \\
\hline Total & &
\end{tabular}

Source: Field Data, October 2007

Financial Framework: Recurring health budget funding on part of the government has gradually increased from 43 per cent in the early 1990s to 63 per cent in 1997/98 (MOH 1999a). 
International donor agencies were expected to fund the remaining part. The annual per capita expenditure for health, including government and external contributions, at the time was USD \$3.95 (MOH 1999b; MOFPED 1998).

The Uganda Essential Drugs Management Programme (UEDMP), now known as Uganda Essential Drugs Support Programme (UEDSP), was founded in 1985 (Okuonzi \& Macrae 1995). Since then, health care has been centred largely on the issue of pharmaceuticals (Danish Red Cross 1999). Considerable funds are invested in pharmaceuticals, tending to make them the focus of the health care system. Drugs have great value on the grey market, and illicit drugs can be purchased in local shops and stands. Several studies pointed to a wholesale disappearance of drugs from public health facilities (Economic Policy Research Centre et al. 1996, Adome et al. 1996).

Recent health reforms have centred on systemic problems and on capacitybuilding in key support systems. The system is primarily underwritten by external funding, although administered by largely unmotivated civil servants. This external funding does not include the payment of salaries, but only covers a per diem for health staff and travel expenses outside the country. This inadequate compensation is partially offset by bonuses that often attract more attention than the job itself. Since funds are generally not requested from below, but distributed from above, there is only a very limited sense of ownership in the items procured or the infrastructure built. Where there is no participatory involvement on the part of the local community or district leaders, or women maintaining district programmes becomes a problem, and many of these health facilities soon end up in a deplorable state (Hultberg 1999).

The heavy reliance on external funding unbalances the system and decreases its long-term sustainability. Most foreign officials are only concerned with specific projects, rather than the overall system. The broadest goal of public health policy, namely the building of a comprehensive and sustainable health care system, receives insufficient attention, while smaller projects or programmes are often over-funded, pursuant to the interests of international donor agencies. Health care is virtually transformed into a biomedical product that is donated to the beneficiaries for their consumption.

In another development, the resource envelope within the Medium Term Expenditure was expected to grow from 4,051 billion in 2005/2006 to 4,276 billion in 2006/2007. In spite of the projected increase in overall expenditure government planned to reduce expenditure on health - 13.7 per cent to 9.7 per cent. The assumption was that government would increase reliance on the provision of health care by the private sector. However, this move has had a negative impact on the welfare of women by reducing household expenditure as well as increasing the burden on home based health care services. 
Women's Role in the Provision and Use of Resources: There is no evidence in the Ministry of Health that women have influenced the process of budgeting so that mainstreamed gender programmes are prioritised. Key positions in the Ministry on policy formulation and implementation are occupied by males as already discussed above.

Integrated Planning: The National Health Policy and Strategic Plan Frame were formulated within the context of the provisions of the constitution of the Republic of Uganda 1995 and the Local Government Act, CAP 243 that provides for decentralised governance and service delivery. In addition, the Health Policy derives guidance from the National Health Sector Reform Programme and the National Poverty Eradication Programme (PEAP). The Policy also strongly reflects the Alma Ata Declaration of Health for All (HFA) strategy. In addition, SWAP has rallied those in the health sector around a single policy and the implementation of a single national strategic plan, and the use of a common management system.

\section{Water Act}

The Water Act came into force in 1995. It provides for the use, protection and management of water resources and supply, the constitution of water and sewerage authorities and facilitates the development of water supply and sewerage undertakings.

Gender Mainstreaming: The Act is gender neutral and even where bodies for the management of water are created; there is no effort to ensure that there is representation of both women and men on the bodies created. This is unfortunate because Uganda is a male dominated society and its institutions are still male dominated.

Participation: In the Ministry of Environment and Water out of sixteen key people involved in policy only five are females as shown in the Table 3.

Table 3: Gender Categorisation of Key Decision Makers in the Ministry of Environment and Water

\begin{tabular}{lcc}
\hline Position & Male & Female \\
\hline Minister of Environment and Water & & 1 \\
Minister of State for Environment and Water & & 2 \\
Permanent Secretary for Water and Natural Resources & 1 & \\
Directors & 2 & 2 \\
Commissioners & 8 & 5 \\
\hline Total & 11 &
\end{tabular}

Source: Filed data, October 2007 
Decisions are made from the position of Commissioners upwards, and if this Ministry has not had a gender awareness and analytical training, it would be difficult to address gender related concerns of men and women. There is no evidence that the Water Act and the National Water Policy were a result of nation-wide consultations in which women would have made a contribution.

Women's Role in the Provision and Use of Resources: In Uganda, women still encounter many barriers to participate in community development activities, including water projects. These barriers include refusal by husbands to attend meetings that address issues of safe water, discrimination, subordinate roles, weak leadership, lack of mobilisation, lack of time and failure to see the benefit of their participation. Their participation in water projects is largely centred on the provision of their labour for unskilled work, often adding to their already heavy workload. Women are generally better maintainers of water facilities than men. Because of their routine involvement in water collection, women are generally aware of the breakdowns and leakage when they occur, and can carry out routine preventive maintenance. Moreover, once trained, women tend to be more reliable and have a lower turn over rate than men who often migrate to look for jobs in towns and the city. This is particularly true of older, married women. Women also have an edge over men because of their greater ease of relating to other women users. Where women have been involved in water committees or other management bodies, they have often been taken as representatives with a passive role and few real responsibilities. In addition, women are rarely, if ever, given training in the organisational and technical skills needed to successfully implement and maintain water projects (Kabonesa and Happy 2003).

Women have been particularly active in the financial aspects of water supply projects such as fundraising, fees collection, keeping funds and the supervision of local boards, due to their perceived willingness and dependability in these roles. In the north east the Karamojong women's groups collect funds for water projects from the sale of traditional beadwork. Once the initial money is raised, the women convince their husbands to make large donations (Alina 1985).

\section{Education Sector}

\section{National Education Policy}

Policies that Promote and Protect the Rights to Education: International standards require that education and educational institutions must be available, accessible (both physically and economically without discrimination), acceptable in terms of cultural relevancy and quality) as well as early adaptable in the context of cultural settings. Furthermore, among other things the State, under the International Covenant on Economic, Social and Cultural rights (Article 13) is enjoined to establish free and compulsory primary education. 
Under the Constitution (Article 30), the right to education is provided for. It is also provided for under the Children's Act. Education is one of the national programme priority areas of the Government of Uganda (GoU). To operationalise this priority which is in the PEAP, MoES developed the Education Sector Investment Plan (ESIP) with the following strategic objectives: to ensure universal and equitable access to quality basic education for all children; to ensure equal access by gender, district and special needs at all levels of education; to improve the quality of education, sports and training at all levels; and to build capacity of the districts by helping education managers to acquire and improve on their knowledge, skills and attitudes to be able to effectively plan, monitor, account and perform other managerial functions. To ensure the provision of education, government has developed and implemented the following programmes:

Universal Primary Education (UPE): In 1997, GoU introduced UPE with the aim to broaden access to primary education. The implementation of UPE has progressively improved over the years, particularly in the areas of training and recruitment of more teachers, construction of more classroom blocks to accommodate the increasing numbers; and purchase of instructional materials. The programme which initially targeted four children per family now covers all children of primary school age. It should however be noted that UPE provides free but not compulsory primary education, hence there are still some children who are not enrolled. Similarly, UPE is only free as far as tuition fee is concerned. Pupils are still required to purchase other scholastic materials like exercise books and pens which some parents find prohibitive. Furthermore, UPE implementation is constrained by huge short-falls of qualified teachers, high pupil classroom and pupil text book ratios all affecting the quality of education.

To ensure that Universal Primary Education is accessed by children all over the country, and specifically the vulnerable areas, GoU together with development partners designed tailored education programme that suits unique circumstances in some remote and difficult areas. These include Alternative Basic Education for Karamoja (ABEK) being implemented in collaboration with Save the Children in Uganda and multi-grade teaching in sparsely populated areas like Kalangala District.

Universal Post Primary Education and Training (UPPET): Following the success of UPE in ensuring free access to education for all children in Uganda, government has come up with the UPPET policy to ensure that pupils who complete the primary school cycle are absorbed into post-primary institutions. The UPPET programme started in 2007. In recognition of the limited capacity of government aided secondary schools, government has 
co-opted private post-primary institutions to participate in the implementation of the programme. It is however observed that the programme is allocated limited resources $(27,000 /-$ per pupil per term), which often affects the delivery of quality education.

There are many challenges to the enjoyment of the right to education. Overall, the effectiveness of these apparently good educational programmes has been questioned by many people. Much as primary school enrolment has improved tremendously over the years following the introduction of Universal Primary Education Policy, the drop out rate is still very high, at 52 per cent in 2006. According to the Ministry of Education and Sports, out of two million pupils who enrolled in primary schools in 1987, only 433,010 (25 per cent) sat their Primary Leaving Examinations in November 2004. The other issue of concern is with regard to the quality of education that children are receiving under UPE. According to a study done under the National Assessment of Progress in Education (NAPE), numeracy levels of Primary Six (P6) pupils has slipped from 41.5 per cent in 1999 to 20.5 per cent in 2003. The study also found out that the performance of children in urban schools was much better than those in rural areas where the majority of children study. The literacy and numeracy levels in P6 in urban schools stood at 40 per cent and 68 per cent respectively in 2003 against 8 per cent and 15 per cent for rural schools. There are also regional inequalities with regard to the delivery of education, especially with respect to the northern region. It has been observed that while many children are going to school, many drop out before Primary five (P5) or graduate without even mastering a minimum set of cognitive skills. This has been attributed to overcrowded classes, poorly qualified teachers, and ill-equipped schools, difficulties by parents to provide lunch, scholastic materials and school uniforms to the pupils. Furthermore, PWDs have not been able to enjoy the right to education because most of the existing schools are not accessible to them in terms of facilities specifically required by PWDs.

\section{Education Act}

The Education Act which is the principle legislation was enacted in 1970. The Act provides for the development and regulation of education, and for registration and licensing of teachers in public and private schools. It is completely gender neutral and fails to take into consideration the gender related barriers to education (FIDA-Uganda 2006:26).

\section{Education Bill 2006}

The Draft Bill proposes to amend, consolidate and streamline the existing law relating to the development and regulation of education and to provide for vocational training. It will repeal the Education Act of 1970 and the Industrial Training Act. 
Gender Mainstreaming: The draft law focuses on opening opportunities for all, regardless of gender.

Participation: The Bill is at the level of Cabinet. There is no evidence of active participation of women organisations/networks during the drafting of the Bill. Even the two members of the Education Service Commission who are females have not been consulted so far to make an input.

\section{Family 'Sector'}

\section{The Energy Policy Process}

In the early 1990s, the Ministry of Energy and Mineral Development identified areas in the energy sector that needed extra attention. One of these areas was electricity. The main focus of the Ministry was first to develop a policy framework dealing with the supply and demand of electricity. This was necessary because the Ugandan government had an ambitious economic recovery programme, with emphasis on the industrial sector. Over the years, pressure increased on the electricity supply capacity that was available. With the pressure and the demands of the economic recovery programme, there was a need to develop policies and guidelines to increase the power supply. Thus, the ministry started with the development of the Power-sector Strategy Plan in the mid-1990s, which provided the framework for the policy, strategy and action plan for the power sector. The main issues in this action plan were the increase of the power generation, the development of new power plants and the privatisation of the Uganda Electricity Board. The plan was based on an already existing power strategic plan, but several stakeholders in the energy policy process found that the plan did not sufficiently cover all the problems in the power sector, like involving the private sector in the energy supply and distribution.

In 2000, with the assistance of consultants from GTZ-Germany, government developed a National Energy Policy. Previously, annual ministerial policy statements had driven Uganda's energy sector on the budget. However, the importance of the energy sector in the economy requires the adoption of a long-term planning approach for energy development. In particular, the liberalisation of the energy sector, in line with the overall macro-economic policies, required the availability of a clear, long-term policy to encourage project development and to harmonise sector activities.

Participation: The energy policy formulation process was driven by the experiences and knowledge available in the ministry. Various groups of expertise within the ministry formed a task force, which collected data by stakeholders through participation and consultation on rural energy, power, 
electrification, petroleum, also including several aspects of gender, like access to resources and energy, use of men and women. After consulting the stakeholders, the task force discussed priority issues and started formulating a first draft. The latter was carried out mainly by staff members of the Ministry for Energy and Mineral Development and the Ministry of Finance and Planning. Then a couple of workshops with the task force and some operators in the sector were organised to put the findings in a report and send the draft of the energy policy to the stakeholders for comments. After receiving the comments from the stakeholders, the draft version of the energy policy was adjusted in relation to the comments. The final document was publicised in September 2002.

From a ministry point of view, one of the problems that were faced in the formulation of the energy policy is the fact that there is no single officer who is in charge of the energy policy at the district level. There are people in charge of water, education, environment, etc., but nobody for energy and neither is energy mentioned in the district plans. So, despite the decentralisation policy of the Ugandan government, it is difficult to involve the local governments in energy policy. Another challenge for the Ministry for Energy and Mineral Development is to see how to integrate energy into the development plan as a whole. In PEAP and the proposed new development plan, energy is prominent and is recognised as having a direct impact on poverty alleviation.

Gender Mainstreaming: Stakeholders participated during the energy policy formulation process, since they were consulted about all the aspects within the energy policy. These were not only public institutions, but also international development organisations, NGOs, CBOs and private companies dealing with energy issues. One of the stakeholders was the East African Energy Technology Network. Although the participants' objectives included integration of gender and women's issues into the policy, specific organisations aiming at women empowerment or gender equality did not participate in the consultation process. Furthermore, although the Minister of Energy and Mineral Development was female at the time, there were hardly women who worked in decision-making positions within the ministry.

The recognition of women's role and energy needs in the energy policy of Uganda is made explicit in some sections of the policy, but mostly the policy speaks about households. Considering the fact that women are the main users and providers of household energy, these sections in the policy are indirectly aimed for women. However, the productive role of women is neglected in the energy policy, in view of the fact that the Ministry did not link the National Energy Policy with the National Gender Policy. Therefore, 
as far as the Energy policy is concerned, women have not made any meaningful participation and impact to achieve gender equality and women's empowerment.

Integrated Planning: The need for an appropriate energy policy is recognised by the 1995 Constitution, which states that 'the State shall promote and implement energy policies that will ensure that people's basic needs and those of environmental preservation are met'. The Poverty Eradication Action Plan (PEAP) also recognises energy as having a direct impact on poverty alleviation. As a result, a partial integrated energy policy was developed, not only looking at one sector of energy, but at all the sectors related to energy; petroleum (both upstream and downstream) supplies, new and renewable sources of energy, and energy efficiency. I refer to integrated planning as partial because a policy that is partially gender compliant cannot be treated as having achieved integrated planning.

\section{The Domestic Relations Bill}

The Domestic Relations Bill (DRB) has a relatively long history that dates back to the 1960s during which period the Government of Uganda (GoU), together with the women's movement, has been working towards having a just family law. The DBR is thus a reflection of a sustained and comprehensive consultative process that aims at consolidating all domestic related laws, namely marriage, divorce, separation, inheritance and property rights...The proposed law is intended to regulate relations in marriage and the family and will be crucial in determining, particularly, the legal status of women and children, thus not only enhancing family but also national stability and ultimately poverty reduction (UWONET 2004).

Gender Mainstreaming: The Domestic Relations Bill is a crucial piece of legislation for Ugandan women. It addresses women's property rights in marriage and women's right to negotiate sex on the grounds of health, sets the minimum age of marriage at eighteen, criminalises widow inheritance. As a compromise measure, bride price will not be prohibited, but the payment of bride price will no longer be essential for the formalisation of customary marriages, and any demands for the return of marriage gifts will be an offence. The bill criminalises marital rape and provides for civil remedies, such as compensation and restricting orders. The grounds for divorce are equally applicable to both spouses and alimony is provided for. The Domestic Relations Bill continues to exclude cohabitation from the presumption of marriage, but provides parties to such relationships with certain rights, including the right to register the fact of cohabitation and particulars of any monetary or nonmonetary contributions made. A competent court may then distribute the 
property equitably in accordance with those contributions, and may do so even when registration has not taken place. Polygamy is also strictly regulated by guidelines that provide for the economic support of all wives. The bill also provides for equal sexual rights and establishes more equitable grounds for divorce.

Participation: The DRB was first tabled before Parliament on 9 December 2003. It was referred to the Committee on Legal and parliamentary Affairs by the House. However, the Bill was not brought back to the House until 2 May 2005. Members of Parliament were ready to debate the Bill but the responsible Minister could not move a motion to have it read for the Second Time because it was considered that sufficient consultations had not been made on the Bill, especially from the Muslim community which strongly opposed the Bill. Parliament requested the executive to inform them of the areas of objection raised by the Muslim community and to present details of these to Parliament.

"When we made the initial attack on the proposed Bill, the law Reform Commission, made several revisions to the report they had prepared. For example, they altered the earlier stand on the number of wives a man may be 'allowed' to marry. Instead of the original position of two wives, they made it four. But they left in place the ridiculous conditions that one must fulfill to be 'allowed' to marry another wife...Anti Muslim forces have intensified to recruit women to their side by drumming up the badness of polygamy. So far there have been no reported cases of success; at the same time this is a matter to watch carefully. However, 'educated' we think we are, Islamic law cannot change to accommodate the wishes of an individual wife whose priority in life is to be an only wife" (Abasi Kiyimba 2000:36-37).

On 9 May 2005 the Minister of justice and Constitutional Affairs made a statement about the contentious clauses of the Bill to parliament. The second reading was adjourned to enable exhaustive consultations with the Muslims and others opposed to the Bill. By the end of the $7^{\text {th }}$ parliament, the Committee on Legal and Parliamentary Affairs had concluded its consideration of the Bill and prepared a report in which it proposed several amendments to the Bill. But because the Bill was not passed into law, it lapsed.

This Bill had reached this far because of significant contribution from women. At the time UWONET headed the DRB Coalition made of up forty eight Civil Society Organisations. The coalition was able to carry out research (UWONET 2004), mobilise various stake holders to appreciate the need to have a consolidated, gender mainstreamed legislation, and organised workshops to strategise getting the Bill Back on to Government's agenda. 
The spirit of participation and contribution of women is captured in some of the voices at the consultative workshop held on 27 July 2006 to strategise how to carry the struggle forward to have the Bill back to the public agenda:

It is not right to say that the process of advocating for the enactment of the DRB has been handled only by elite women; over the years it has involved many women and a wealth of information has been collected (Kakooza 2006:55).

There is no single piece of legislation in Uganda that has had as much research as the DRB, which is very telling. Once one attempts to change power relations within the family, this is bound to change each and everything within and outside the family by one stroke of one piece of legislation. This certainly spills over. This is why the struggle has taken this long (Kakooza 2006:55).

The DBR has not been passed as law which would promote gender equality and women's empowerment for a number of reasons: i) limited awareness about its provisions resulting into a misconception that it is intended to promote alien (western) culture; ii) misinterpretation as a women rather than a gender concern; iii) inadequate conceptualisation as a development/poverty issue; iv) the misconception that it is elitist, having nothing to do with the rural poor; v) the protectionist interests of female and male advantaged members of society, who fear that they will be dispossessed of their property; vi) the fear, by especially the men that it will reverse the social order and promote female privilege; and vii) resistance to change arising out of the deeply ingrained cultures, norms and values (UWONET 2004:ix).

Apart from the DRB, women have engaged the state to challenge laws that oppress them. The Divorce Act for example, (came into force in 1904) which applies to persons that are domiciled/permanently resident in Uganda), was challenged by women organisations as being discriminative. This is yet another example that illustrates women's attempts to force the government (through litigation) to make non-discriminatory laws. In their judgment in FIDA (U) \& Others v. Attorney General (Constitutional Petition No. 2 of 2003), their Lordships of the Constitutional Court all agreed that the above provisions of the Divorce Act are contrary to the stated provisions of the constitution, to the extent that they are discriminate on the basis of the sexes and are therefore void. They ruled that in the application of the Act, the provisions should apply to husband and wife equally but observed that the application of their order was likely to meet difficulties. Parliament was therefore advised to take appropriate remedial action which it has failed or refused to take (UWONET 2006). This case is a good example of women's contribution to gender mainstreaming of legislations and exposure of the government's reluctance to operationalise the constitutional provisions for women's equality and empowerment. 


\section{Local Government Act}

Gender Mainstreaming: The Local Government Act CAP 243 provides that women must form at least one-third of the total number of councilors at all levels of councils, from the village to the District. This is aimed at ensuring participation of women in decision making. Gender mainstreaming and in particular the participation of women in capacity building activities, and sensitisation on gender issues have been made indicators of minimum conditions and performance measures during the annual assessment of local government's performance. In this way, it operationalises the constitutional provisions for affirmative action by providing for one-third of the seats in each local council to be reserved for women. The Act also provides for affirmative action with respect to other marginalised groups (people with disabilities, youth, the aged, etc.) in the composition of local councils. These provisions have resulted in a significant increase in the number of women in political decision making at the different levels of the local government (i.e., district councils, sub-county councils, city division councils, municipal councils, municipal division councils and town councils).

The increased representation of women in decision making structures of local government is especially significant in the context of decentralisation, as substantial powers have been devolved to lower levels of government where policies, budgets and development plans are made. This means that at the Local Council Three (LC III) level, which is the lowest governance structure for planning and budgeting, at least one-third of the councilors in the 954 sub-county, town, and municipal councils are women. This number is further boosted by women representatives of youth, people with disabilities and the elderly and women councilors elected or nominated on the 'nonaffirmative' tickets.

Participation: Women organisations and Members of Parliament (MPs) were very active in the formulation of the Local Government Act. Women have also been active in the implementation of the Act particularly in the electoral politics and representation. However, their participation has not resulted into the desired impact as far as resource allocation is concerned in terms of training in gender analysis, maternity health etc. Uganda, for example, still experiences high death rates of mothers during delivery periods.

Integrated Planning: The Local Government Act was formulated under the movement system. A number of women groups participated during sensitisation and consultation workshops. The law reflects the spirit of gender mainstreaming. However, with the introduction of multiparty system in Uganda there is an urgent need to review the law to be consistent with the new system. This is an opportunity for women activist groups to influence legislation to have more gender equality and women's empowerment. Areas 
to focus on include budgeting, involvement of women in implementation of policies, and fair representation of political parties in committees according to their strengths in councils.

\section{The Land Act}

The Land Act 1998 is Uganda's principal legislation on land. It provides for tenure, ownership and management of land and was amended by the Land (Amendment) Act 1 of 2004.

Gender Mainstreaming: The Land Act makes an effort to preserve the rights of women, children and persons with disabilities to the use of customary land in section 17. Any decision taken in respect of land held under customary tenure - whether held individually or communally - has to be according to the customs, traditions and practices of the community concerned. However, a decision that denies women, children or persons with disability access to ownership, occupation or use of land or imposes conditions that are in contravention of relevant provisions of the constitution which entrench their rights, is null and void.

Until 2004, the main provision protecting family interest in land was S.39 of the Land Act. The provision prohibited spouses from dealing in land from which a 'family derives sustenance' without written consent of the other spouse and their offspring. The provision still provides some protection to women in marriage but it does not extend its protection to couples cohabiting. In addition, the Land Amendment Act of 2004 removed the requirement of consent of the offspring to dealings in land by their parents. This condition was because it was argued that adult offspring were frustrating the development of land markets by unreasonably withholding their consent to parents' transactions in land. As a result, the Land Act is now devoid of protection of children's rights to stay on family land (UWONET 2006:21). Section 19 of the Land Amendment Act, 2004 introduces a new section 38A to the Land Act and provides for security of occupancy of spouses. Security of occupancy means a right to have access to and live on family land. 'Family land' is then defined very broadly as land on which the ordinary residence of the family is situated, and land from which the family home shall be situated, or which the family agrees that they derive sustenance from. Land from which the family derives sustenance is also defined to mean land which the family farms, or land which the family treats as the principal place which provides the livelihood of the family.

Participation: Women, particularly members of Parliament were very active in the formulation of the Land Act. They were supported by women organisations that had interest in gender mainstreaming the land issues. 
Similarly, participation was reflected during the struggle to have co-ownership clause in the Land Act as we shall explain shortly and it is also reflected in the on going consultations to have a broad and more inclusive land policy.

The role of women in the provision and use of land resource: Legal provisions for spousal co-ownership still elude Ugandan women in spite of the fact that there is strong evidence for support for spousal co-ownership of land indicated in the 2005 Gender Monitoring Baseline Survey. The over all approval rating for spouses to co-own land was found to be 61.4 per cent and the disapproval was 24.6 per cent. All regions of the country gave ratings above 50 per cent. The most disappointing period was in 1998 when the coownership clause was introduced in parliament to form part of the law on land. Despite the support it had during the debate in Parliament, when finally the Bill was passed and the President assented to it, the co-ownership clause was missing. Why didn't the responsible persons put such an important clause agreed upon during the debate in Parliament in the final text? The answer could be perhaps the male domination on important organs of Parliament that scrutinises final texts passed by Parliament.

\section{Table 4: Gender Representation on Key Decision Making Positions in the Ministry of Lands, Housing and Urban Development}

\begin{tabular}{lll}
\hline Position & Female & Male \\
\hline Minister & & 1 \\
State Minister & 3 \\
Permanent Secretary & & 1 \\
Directors & 2 & 1 \\
Commissioners & 2 & 1 \\
\hline Total & & 7
\end{tabular}

Source: Field Data, October 2007

\section{The EOC Act 2006}

In December 2006, the Parliament of Uganda passed the Equal Opportunities Commission (EOC) Bill for the establishment of the commission. Earlier on, the Government of Uganda had passed the National Equal Opportunities Policy. Article 32(3) states that 'there shall be a commission called the Equal Opportunities Commission whose composition and functions shall be determined by an act of Parliament'; and Article 32(4) enjoins Parliament to establish the Equal Opportunities Commission within one year after the coming into force of the Constitution Amendment Act, 2005 (30 September 2006). 
The purpose of the Act is to provide for the composition and functions of the Equal Opportunities Commission which ensures constitutional national objectives and directive principles of state policy which, among others, provide for gender balance and fair representation of the marginalised, protection of the aged, balanced and equitable development, and recognition of women in society, recognition of the dignity of PWDs.

The Act therefore provides an institutional framework for the purpose of promotion of equal opportunities, elimination of discrimination and giving full effect to the principle of affirmative action in favour of marginalised groups for the purpose of redressing imbalances which exist against them. These include persons discriminated against on the basis of, but not limited to sex, race, colour, ethnic origin, tribe, birth, creed or religion, social or economic standing, political opinion, disability, gender, age, or any other reason created by history, tradition or custom.

Gender Mainstreaming: Part 3 of the Act - Functions and Powers of the Commission - provides that the Commission will monitor, evaluate and ensure that policies, laws, plans, programmes, activities, practices, culture and customs of: organs of the State, statutory bodies, public bodies, private business and enterprises, non-governmental organisations, and social and cultural communities are compliant with equal opportunities and affirmative action.

Participation: In November 2002, Action for Development (ACFODE) organised an EOC consultative meeting with different stakeholders advocating its establishment. The purpose of the meeting was to give an update to the stakeholders on the processes geared towards the establishment of the EOC, identify challenges and gaps faced in the struggle to realise its establishment and bring on board more stakeholders to complement each other. ACOFDE's initiative resulted into a coalition of advocacy for the establishment of an EOC. Members of the coalition included: NUDIPU, FIDA-U, NACWOLA, NGO-Forum, UWONET, UMWA, ANPPCAN, and UNASO, Friends for Peace and Religious Tolerance, and FOWODE.

In November 2003, ACFODE organised an EOC consultative meeting with different CSOs and activists advocating for and working with the marginalised groups. The coalition held several strategic planning meetings and developed an advocacy and media strategy to ensure an effective campaign for the establishment of EOC. The media campaigns included the use of newspaper articles and supplements, radio talk shows, media spots, press conferences and press statements. Information, education and communication materials such as posters, fliers, brochures and calendars were developed on marginalisation and discrimination. The Ministry of Gender, Labour and Social Development was involved as a strategic partner in planning and facilitation in collaboration with the Netherlands Development Agency - SNV. 
The coalition organised other activities that put pressure on the government to establish the EOC. In September, a petition was presented to the Speaker of Parliament and was forwarded to the Legal and Parliamentary Affairs Committee. The petitioners demanded that article 32(2) of the 1995 Constitution be maintained and an independent EOC be established. They also demanded that Parliament enacts a law to establish and operationalise the EOC and that the functions of the EOC which were delineated to the UHRC be redirected to the EOC. A peaceful demonstration to Parliament was held to support the establishment of EOC in 2003.

On 27 February 2005, the coalition made a presentation to the Legal and Parliamentary Affairs Committee on the then published Constitutional (amendment) Bill 2005, on establishing an independent EOC, its composition, functions, tenure of office and a time frame for its establishment and operationalisation, among others. The coalition also became a member of the national task force that coordinated the activities of the EOC.

It is important to note that the coalition spearheaded by a women's organisation, and the Secretariat of the Ministry of Gender, Labour and Social Development refined and presented the EOC working bill to the Legal and Parliamentary Affairs Committee for incorporation into the Constitution (Amendment) Bill, 2005 at the request of the Committee. Studies were carried out by CSOs, workshops were held on awareness raising. In particular, on 10 November 2006 ACFODE organised a workshop with 30 MPs where CSOs presented their concerns over the status of the Bill, before Parliament passed it. The major concern on the Bill was that the Commission should not be toothless but with powers to bite. On 12 December 2006, Parliament passed the law on equal opportunities.

Although the EOC has not yet been established, the above experience shows how women have organised and made modest contribution towards the empowerment of marginalised groups through a progressive legislation and policy in Uganda. What is surprising is the reluctance of the government to put in place the commission and the secretariat to implement the ideals of affirmative action.

\section{Assessment}

Affirmative Action: It is clear that the momentum and remarkable unity of purpose and effort by women, which was depicted during the Constituent Assembly process and which resulted in the positive impact on the constitutionmaking process was not sustained after the passing of the Constitution. The problem is that women's organisations and networks mobilise and organise on ad hoc basis for particular issues rather than having a sustained and focused struggle on gender equality and women's empowerment. As a result, 
women as beneficiaries of affirmative action have not done enough to shape its interpretation, monitor its implementation and ensure that its provisions are enforced.

As Kharono (2003:11) observes:

The weak sense of ownership of affirmative action among women and their various organisations and networks has contributed to the continued perception that affirmative action is a gift from the NRM government rather than a right. That this perception persists, notwithstanding the constitutional provisions, illustrates the failure of its proponents to own, engage and define its content and develop a coherent and strategic agenda on its implementation. Given this failure, it is not surprising that a large number of women beneficiaries of affirmative action not only feel obliged to the NRM government, but also dare not challenge the status quo. They find it easier to fit into, rather than transform systems cultures and structures that have marginalised them, which is the intended purpose of providing for affirmative action in the constitution.

The challenges proponents of affirmative action face are compounded by the institution and practices of patriarchy that are still strong in the Ugandan society. Patriarchy here is understood as a systemic male dominance in economic, social, cultural and political spheres. It validates male values, behaviour and privilege.

Water Act: There is need to mainstream gender in water resources management in order to give adequate consideration to the roles, needs, access to and control over resources and decision-making of both women and men. Mainstreaming gender in policy and programme development must be recognised in relation to the overall programmes and in specific areas such as UPE/UPPET, energy, etc river basin development and management.

Gender weakness still prevails at the government, private and individual levels in the provision of water service. With liberalisation, government opened up opportunities for private companies and individuals to bid for contracts of constructing wells and hand bumps. There is still a lack of gender sensitivity in recognising women as participants, change agents and beneficiaries. Nevertheless, there have been some positive changes in laws which see gender being worked on in the government sector. One big problem is that written concepts are yet to be put in practice. Policy and practice seem in isolation with each other, so practising the concept prior to gender mainstreaming is necessary.

Gender Mainstreaming: Women's participation in the planning, designing, implementation and management of projects or programmes developed by outside agencies should ensure that the systems meet the demands of women, and that they function better. Women's involvement is necessary throughout 
the whole project process, from planning to sustainability, to make a difference; and yet this has eluded policy implementers in Uganda.

The design of the projects should go beyond the practical needs of women for more and better quality services. They need to be able to involve women in a range of ways, including their meaningful (not token) participation in decision-making at all levels. These projects need to be used as leverage for addressing gender inequalities at the community level, otherwise women's participation will remain peripheral, and the range of needs they have (for example income generation and for more involvement in community decisionmaking) will remain unmet.

Successful influence by women on selected policies/legislations and the resulting projects in meeting women's gender needs should be measured using these criteria: women's participation in project activities; changes in the traditional gender division of labour; women's access to and control over resources; equity in sharing of benefits; and women's improved status and involvement in new development initiatives. The evidence on the ground shows that implementation of programmes at the local level in health, education, and family sectors is opposite to what the laws and policies espouse.

The implementation of programmes that ensure promotion of the rights of women are hampered by the meager resources that are allocated to it by government, both at the centre and at the local government (LG) level where they share an allocation of barely 1 per cent of the budget with other activities. Unfortunately, in most cases, it is not actually released. As the former Minister for Gender, Labour and Social Development observed:

The Beijing platform for action emphasised the importance of identifying and mobilising resources from all sources and across sectors. But now time has come to transform commitments into reality through action... I strongly hope that this meeting will be a further step in women's progress towards empowerment and a call for firm, resolute and specific actions on financing for gender equality (Ms Syda Bbumba while officiating at the opening of the Common Wealth Women's Network Workshop, Hotel Africana, Kampala, 20 November 2007; Daily Monitor, 22 November 2007).

Programmes for gender which get implemented are those which are donor funded. Few projects allocate enough preparation time for gender responsiveness. Many of them are time bound and target oriented which reduces the scope for gender sensitive works that often require a lot of time.

Another challenge is that often, a lot of project work is piecemeal and uncoordinated, run by agencies and within communities where little gender sensitisation has taken place and where awareness and understanding of gender inequality is low, thus leading to poor results. 
Trying to focus on many things in many places could turn out to be too ambitious and can in itself be a weakness, because the volume of work becomes enormous. There is also the fact that not all people working in the public sector have skills in gender analysis and not everyone has the capacity to be able to identify gender issues and design appropriate interventions to address them.

The Land Act: The recent legal changes have had no significant impact on women's land rights in Uganda. Women's tenure on land continues to be dependant on the rights of husbands, and other male relatives. The 2005 Gender Monitoring Baseline Survey for the Land Sector Strategic Plan (LSSP) found that only 3 per cent of spouses in Uganda co-own registered land. Male ownership of land still predominates in all regions with only about 16 per cent of women holding registered land (UWONET 2006). Despite the women's efforts to have a co-ownership clause in the Land Act, both in 1998 and during Land Amendment Bill 2003, they lost the battle and instead settled for the right of occupancy which unfortunately can only be enjoyed by a woman during her husband's lifetime.

Health Policy: In the health sector, the interpretation of gender has traditionally referred to reproductive health care for women. While this may improve services for mother and child, it may neglect other health problems for women. Focusing on reproductive health care tends to neglect the fact that gender inequality itself can lead to ill health among women. Women face particular barriers in reporting and seeking healthcare, and so being a woman may be one of the major predisposing factors for ill health. Their low status in society and household limits the availability of resources to pay for services. Financial constraints in the health care system pose significant challenges; for instance, user fees impose a heavy burden on the most vulnerable groups, especially women. Cultural factors may also severely limit women's access to health services like in cases where they are restricted from consulting male health workers, as well as lacking time to visit health units. Patriarchal practices like wife battering are seldom reported to medical workers due to the fear of cultural stigmatisation and additionally, women's special needs such as privacy, which are determined by social norms, are often not met in the services offered (CEEWA 2002). Therefore, despite the existence of the National Health Policy and other policies and legislations, women have not been able to make the desired impact to promote gender equality and women's emancipation in the health sector.

Equal Opportunities Act: Before 2006, the absence of an implementation framework informed by appropriate policy, law and institution was a major weakness for affirmative action. Once the commissioners and the Secretariat are put in place, the EOC will provide the framework for the purpose of 
equal opportunities, elimination of discrimination and giving full effect to the principle of affirmative action in favour of marginalised groups. Women made a contribution to reach the current stage, but there is more to be done to have the EOC established and functional according to the principles embedded in the constitution.

Education Bill: It has been established that UPE did not introduce affirmative action for the girl children in education but simply opened up opportunities for more children, who would otherwise not have been able to afford basic education to obtain it. It is clear that emphasis has been on improving access for all without particular emphasis being given to the girl child. The government left it to parents to decide which children would enjoy this facility. This mechanism has not checked the socio-cultural factors that make parents to give preference to the male child. There is evidence to show that there is disproportionate school drop-out rates of boys and girls where socio-cultural factors work against the girl child (UBOS, Socioeconomic Survey:2002/2003).

Furthermore, in spite of the fact that early pregnancy has been found to be one of the factors that hinder the advancement of girls in the education system, the Bill makes no provision for dealing with this problem. Additionally, despite the fact that the MOES passed a policy outlawing corporal punishment, and the constitutional Court has pronounced that meting out corporal punishment is contrary to provisions of the constitution, no provisions have been included in the proposed law to deal with it. The above gaps, like in other proposed legislations, show how much there is to be done to mainstream laws and have them implemented.

Advocacy: While there seems to be a relatively progressive political environment, policy advocacy work is still vital if women empowerment is to be achieved. Examples of progressive laws and policies which have been put in place by GoU include the 1995 Constitution, the National Gender Policy, the National Action Plan on the Advancement of Women, the affirmative action provisions in the Local Government Act, the Health Policy and Energy Policy.

Similarly, several institutions geared towards supporting the advancement of women have been strengthened or developed in the country over the last twenty years. These include the women NGO, the women community based organisations, the donor committee on gender, and the Ministry of Gender, Labor and Social Development.

However, unfair laws, and negative customary practices and beliefs that impinge on the rights of women are still dominant and, when coupled with the level of poverty in the country, make women and girls lag behind men in all the social, political and economic aspects of life. 
It is clear that the policy advocacy work that has been done has not engaged extensively with the key government processes such as PEAP, sector wide planning such as the Plan for Modernisation of Agriculture, and has thus tended to be marginalised and not received the attention it deserves. This has been worsened by the lack of a consistent unified and coordinated voice on gender issues by GoU in collaboration with the civil society and by the fact that the unity among NGOs is often short lived. It is high during peak times of the advocacy campaigns and weakens if the advocacy aims are not achieved within a short time. This affects the availability of a consented and collective influence on government and donor policies.

Programmes geared towards achieving the government commitments to women empowerment are not systematic and lack publicised benchmarks which make it difficult to hold the government accountable. This situation is worsened by the fact that most of the pressure from gender focused NGOs on government to honour its commitments has had limited participation of the grassroots women and men mainly because of the ineffective strategies or adequate financial and skilled human resources. In fact, policy advocacy is dominated by Kampala based National NGOs with limited resources from donors. Likewise, institutions have limited skills in gender and policy advocacy, which impinge negatively on their work.

This is why it is important to understand where power lies in the process of gender advocacy. Power lies in customary laws and practices which govern the community, the men to whom customs have accorded more power, the government which makes policies, the donors who provide the resources and the women and men at the grassroots who are victims but also agents of change through the socialisation process.

Policy advocacy cannot be an end in itself but is a means to an end, and hence, the call for integrated programmes where it is one of the strategies used to change the quality of lives of poor women. It also means that for policy advocacy to succeed, direct investments need to be made in programmes aimed at poverty alleviation. Ways need to be explored to reduce the woman's work load so as to give her time to engage in initiatives aimed at enhancing her social status beyond the household, rather than being complacent as Tamale (2001) submits:

Thus more often than not, the beneficiaries have felt an allegiance to government for having given them this opportunity and have fallen into traps of complacency and self-satisfaction rather than advancing the concerns of women.

\section{Policy Recommendations}

The paper has identified gaps both in the existing selected policies and legislations vis-à-vis women's contribution according to the benchmarks 
set. The recommendations that follow are aimed at increasing the contribution of women, particularly organisations and networks working for gender equality and women's empowerment. My proposals are out of conviction that social science research organisations, civil society organisations and civilian think-tanks (including women's organisations and networks) have an important role to play in this endeavor, as repositories of knowledge, advocacy, popular participation, accountability and empowerment.

Gender Mainstreaming: There are areas which lack policy and legislation. Therefore, women's participation in both formulation and implementation is crucial. Examples include laws on the education of adolescent mothers schools still largely exclude them from continuing in the education system; laws prohibiting corporal punishments in schools; a sexual offences law this would address issues like prostitution, homosexuality, lesbianism, bisexuality; domestic violence and female genital mutilation; laws on conflict and peace building policy; laws that regulate micro finance institutions etc. It is also necessary to advocate the enforcement of the already existing laws and policies in mainstreaming gender.

Gender and Equity Budgeting: Women organisations/networks should get more interested in the budgeting process in the health and education sectors where inadequate resources are provided for health and education needs of women, both at the local government and national levels. They should also acquaint themselves with the operation of sector-wide approaches (SWAP), which is a government's macro-economic framework within which Medium Expenditure Frameworks determine the resource allocation for a sector. It includes definition of an overall sector policy framework, prioritisation of objectives, expenditure programmes, capacity building and joint administration and financial management. Women leaders and activists should therefore train and gain skills in public policy and gender sensitive analysis. For women to effectively participate in development issues, they must be trained and empowered in the gender budgeting process.

Domestic Relations Bill (DRB): There is urgent need to review the contentious sections that are holding up the whole process of enactment of the Bill into law because, if enacted, it has the potential to address gender based inequalities such as land rights, decision making and the invisibility of women's work, all of which are core gender dimensions of poverty in Uganda. It is therefore important for women coalitions to move quickly and get the DRB back onto Government's agenda. Women need to continue pressurising government for the enactment of the laws on inheritance, sexual offences, domestic violence and women's land rights. 
The Local Government Act: This law largely reflects the movement system previously adopted in the country, so it must be reviewed to make it consistent with the multiparty system. This is where women organisations and networks should participate so that strategic gender needs are not sacrificed to partisan interests. Strategic gender needs refer to the long-term needs of women and men in their struggle towards empowerment and women's emancipation, thus challenging the prevailing gender inequalities. Consequently, it is high time women thought of reviving their gender movement beyond their different political party ideologies and interests.

Education Policy/Bill: This should be reviewed to enhance the government's commitment to the girl child. GoU should step up efforts that ensure increased enrollment of girls and their progression throughout the education system. In addition, women organisations and networks should continuously sensitise parents and guardians on the socio-economic conditions which limit the girl child's progression in education.

Advocacy: The good practices that emerged during the coalition advocacy activities on Equal Opportunities Commission should be utilised in other policy and legislation formulation process and implementation. Such good practices as the use of public dialogues; frequent updates on the progress to stakeholders and individual human rights activists; use of various methods of mobilisation such as writing letters, emails and telephone calls; team work and voluntarism; use of newspaper supplements capturing a wider coverage of society and information dissemination to MPs, and mobilising them to participate in debates on the subject matter, both in and outside the house, should be maintained.

Engaging the Government: The fact that the government has been reluctant to put in place the main institutional framework for affirmative action, that a number of legislations that oppress women have not been amended and that inadequate resources are allocated to programmes that would promote gender equality and empowerment of women (what others call lack of political will), calls for women coalitions to engage the government on the basis of the constitutional provisions and rise up to the occasion of demanding compliance to the supreme law of the land. This however requires unity of purpose that takes a bi-partisan approach under a multi-party dispensation. Therefore, it is necessary for women to come together and ask for accountability from the government in relation to affirmative action.

\section{Conclusion}

The paper sought to interrogate the contribution of women in influencing legislation and policy formulation and implementation in Uganda between 1995 and 2005 in the health, education and family sectors. I have argued that although the government has been implementing a gender sensitive and 
responsive constitution, and despite the fact that the number of women participating in politics and governance has been steadily increasing, their participation has not had the desired impact on legislations and policies to make them gender sensitive and responsive to women's rights, interests and needs.

This state of affairs is explained thus: First, women as beneficiaries of affirmative action have not done enough to shape its interpretation, monitor its implementation and ensure that its provisions are enforced. Second, the government has demonstrated on several occasions its reluctance (what others call lack of political will) to operationalise the constitutional provisions for gender equality and women's empowerment. Third, the patriarchy institution is still strong, and this makes conditions for empowerment in Uganda very problematic.

The paper however recognises some achievements in terms of the constitutional provisions, institutional and political framework in place which women and society can build on to achieve greater gender equality and women's empowerment.

The paper also proposes policy recommendations which, if properly implemented, would go a long way to scale up women's impact on policies and legislations for gender equality and women's empowerment.

\section{References}

ACFODE, ARISE, A Women's Development Magazine Issue No. 41, March 2007. ACOFODE, ARISE: A Women's Development Magazine Issue No. 40 December 2006. ActionAid Uganda, 2000, Draft Country Programme Review Report, Kampala: ActionAid Uganda.

Adome, R.O., et. al., 1996, Popular Pills, Community Drug Use in Uganda, Amsterdam: Het Spinhuis.

Alina, R.S., 1985, ‘Women's Role in Water’ in P. P. Kabalikat, ed, Women's Issues in Water and Sanitation: Attempts to address an Age-old Challenge. IDRC, Canada.

ARISE, A Women's Development Magazine, Issue No. 39 August 2006.

CEWA-Uganda, 2002, Participants Notebook: Integrating Gender into Economic Policies, Kampala: CEWA(U).

FIDA-U, 'Shadow Report of Uganda's First Periodic State Report to the African Commission on Human and People's Rights' Presented to the $40^{\text {th }}$ Ordinary session of the African Commission on Human and people's Rights, Banjul, the Gambia 15-29 November 2006.

Kabonesa, C. and Happy, M., 2003, The Gender Gap In Water Resource Management In The Nile Basin Countries: The Case for Rural Women in Uganda, Paper presented at 'Role of NGOs and Media in the Nile Basin Initiative’ Session, March 16, Kyoto, Japan. 
Keller, B., 2002, ‘Engendering Uganda’s Poverty Eradication Initiatives: A Desk Review on Gender and Poverty', Report for Ministry of Gender, Labour and Social Development, Ministry of Finance, Planning and Economic Development and Department for International Development (DFID).

Kharono, E., 2003, Critical Review of Affirmative Action in Uganda, Kampala: UWONET.

Kiyimba, A., 2000, 'The DRB: The Issue is not the Number of Wives' in ARISE: A Women's development Magazine Published by ACFODE No. 29.

Matembe, M., 2002, Gender, Politics and Constitution Making in Uganda, Kampala: Fountain Publishers.

MFPED Poverty Eradication Action Plan 2004/5 - 2007/, Kampala.

MFPED, 2006, Gender Inequality in Uganda: The Status, Causes and Effects.

MGLSD, Gender Bulletin, Vol. 9 No. 2000.

Ministry of Finance, Planning and Economic Development (2006), 'Gender Inequality in Uganda: The Status, Causes and Effects' Discussion Paper 11.

Ministry of Gender, Labour and Social Development, 1999, The National Action Plan on Women, Kampala: Uganda.

Ministry of Gender, Labour and Social Development, 1999, Third Country Status report on CEDAW, Kampala: Uganda.

Mulyagonja, I.K., 2006, Domestic Relations Bill Coalition: Report on Background Study for Re-Strategizing for Enactment of an Equitable Family Law for Uganda, Kampala: UWONET.

Okuonzi, S., and Macrae, J., 1995, Whose Policy is it anyway? International and National Influences on Health Policy Development in Uganda, Health Policy and Planning 10(2):122-132.

Republic of Uganda, The 1995 Constitution.

Republic of Uganda, The Local Government Act, CAP 243.

Ssonko, M.N., 2002, 'Working in Gender and Development in the Ugandan Context', A paper Delivered to the Students of Gender and Development Policy, University of Wales Swansea, School of Social Sciences and International Development.

Tamale, S., 2001, Women's Participation in Politics, Strategies for Parliamentary and Local Council Elections 2001, Keynote address at a Women's breakfast meeting in preparation for the Ugandan Parliamentary and local government elections 2001, organized by the East African Sub-regional Support Initiative for the Advancement of Women (EASSI), March 23rd, 2001 at Sheraton Hotel, Kampala.

UBOS, Socio-Economic Survey, 2002/2003.

Uganda Women's Network: Domestic Relations Bill review report 2001.

UWONET, 2004, Gender Transformation and Empowerment: The Domestic Relations Bill and The Poverty Eradication Action Plan, Exploring the Linkages.

UWONET, 2006, Gender Audit of Key Laws Affecting Women in Uganda.

UWONET, News, Vol. 7 Issue No. 1 August 2005. 